\title{
蒸留水を試料とする円偏光フェムト秒レーザー誘起パルスX線発生
}

\author{
佐藤 大輔 ${ }^{1}$, 松島 進一 ${ }^{1}$, 小野博司 ${ }^{1}$, 梶本 真司 $^{1}$, 福村 裕史 $^{1}$, 畑中 耕治 $^{2}$ \\ ${ }^{1}$ 東北大学大学院 理学研究科化学専攻 ( T980-8578 宮城県仙台市青葉区荒巻字青葉) \\ 2 東京大学大学院 理学系研究科附属超高速強光子場科学研究センター（ ₹113-0033 東京都文京区本郷7-3-1)
}

\section{Circularly Polarized Femtosecond Laser-Induced Pulsed X-Ray Emission from Distilled Water}

\author{
Daisuke SATO, ${ }^{1}$ Shin-ichi MATSUSHIMA, ${ }^{1}$ Hiroshi ONO, ${ }^{1}$ Shinji KAJIMOTO,${ }^{1}$ \\ Hiroshi FUKUMURA, ${ }^{1}$ and Koji HATANAKA ${ }^{2}$ \\ ${ }^{1}$ Department of Chemistry, Graduate School of Science, Tohoku University, Aramaki, Aoba-ku, Sendai, Miyagi 980-8578 \\ ${ }^{2}$ Center for Ultrafast Intense Laser Science, School of Science, The University of Tokyo, 7-3-1 Hongo, Bunkyo, Tokyo 113-0033
}

(Received August 28, 2009)

\begin{abstract}
Circularly-polarized or linearly-polarized femtosecond near IR laser pulses were used as excitation for pulsed X-ray emission from distilled water solution. X-ray intensity and electron temperature were highest when the laser was linearly p-polarized, while the intensity and the temperatures decreased as the s-polarization component of laser increased in addition to the p-polarization component whichever the total laser polarization was circular or diagonally-linear. These results indicate that processes of multiphoton ionization, electron acceleration, and resonance absorption leading to X-ray emission are inhibited by the s-polarization component of the excitation laser pulses.
\end{abstract}

Key Words: Femtosecond laser, Distilled water, X-ray emission, Circular polarization

1. はじめに

集光強度にしてペタワット $\left(10^{15} \mathrm{~W} / \mathrm{cm}^{2}\right)$ を超える高強 度レーザー場と物質との相互作用の結果, 従来のアブ レーションやプラズマの生成にとどまらず, パルスX線

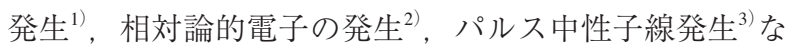
どが誘起される。 その他にもレーザー振動電場による分 子の変形 ${ }^{4)} \mathrm{PC}_{60}$ のCoulomb爆発 ${ }^{5)}$ など, 従来の光化学. 光物理とは異なる現象も多く報告されており, 高強度 レーザー場における電子の振る舞いに関する理論的アプ ローチ ${ }^{6)}$ と併せて, ペタワットレーザー場と物質との相 互作用に関する研究が飛躍的に進みつつある。 なかでも パルスX線発生は, 多光子イオン化, トンネルイオン 化，高強度レーザー場に扮ける電子加速，レーザーパル ス幅内における散乱・内殼励起など, 基礎科学的にも興 味深い過程が多く関与していると考えられ，高強度レー ザーパルスと物質との相互作用として様々な議論が行わ れているだけでなく ${ }^{7-9)}$, 種々の時間分解測定のための 光源として注目されている

パルスX線発生に関しては，これまで固体ターゲッ ト ${ }^{16)}$ ，気体ジェットターゲット ${ }^{17)}$, 液体ターゲット ${ }^{18,19)}$ 等をもちいて多くの研究がなされてきた。一方でこれら の研究において直線偏光励起に関する報告例は多く見ら れるものの, 円/楕円偏光励起に関する研究例は極めて 少ない.こうした状況の中我々の研究グループでは,
フェムト秒レーザー誘起X線発生のための媒体として水 溶液に着目しこれまで実験，研究を行ってきた ${ }^{20-24)}$ 。水 溶液を試料としたX線発生においては，種々の溶質を溶 解することにより任意の特性X線を発生させることがで きる点, 循環装置を用いることにより長時間安定にX線 を発生可能である点で, 基礎研究・応用双方の観点から 優位であると考えられる。他の研究例同様これまでp偏 光励起を中心に実験を行ってきた，本稿では，上述する 背景をもとに, 円/楕円偏光励起ならびに直線斜め偏光 励起に関する実験結果について報告し，その特徴に関し て考察を試みる。

\section{2. 実 験}

実験の概略図をFig. 1に示す．励起光源として中心波 長775 nm, パルス幅390 fs (ネガティブチャープ), 繰り 返し周波数 $1 \mathrm{kHz}$ ，プレパルスとのコントラスト比500： 1 程度のフェムト秒チタンサファイアレーザー(ClarkMXR/CPA2001，PositiveLight/EvolutionX)を用いた。こ れまでにネガティブチャープで照射した時に最高X線強 度が得られる ${ }^{23)} こ と か ゙$ 知られているので, 比較的長いパ ルス幅のレーザーパルスを採用した。またレーザー照射 角度は液膜の法線に対して60度とした。試料にはマグ ネットポンプにより $150 \mathrm{ml} / \mathrm{min}$.の流速で循環させ，幅 $100 \mu \mathrm{m}$ の噴出口を持つ $\mathrm{Ti}$ ノズルから噴出させた蒸留水膜 
(a) Circular pol. ex.

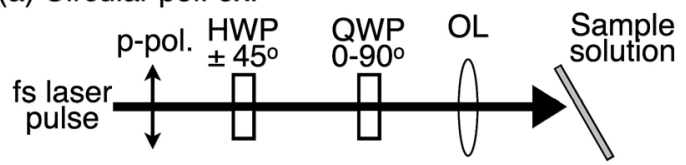

(b) Linearly-diagonal pol. ex.

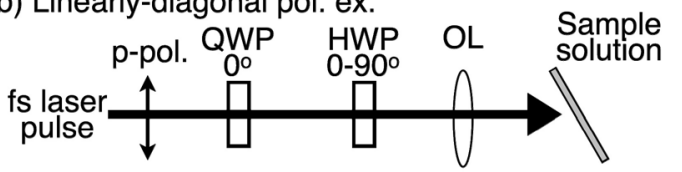

Fig. 1 Experimental setup for femtosecond laser-induced $\mathrm{X}$-ray emission from a distilled water flow.

を用いた。このときレーザーの照射位置での試料の噴出 速度が液膜厚 $100 \mu \mathrm{m}$, 液膜幅 $15 \mathrm{~mm}$ から $1.7 \mathrm{~mm} / \mathrm{ms}$ と見 積もられ，焦点位置でのレーザースポットサイズが約 $20 \mu \mathrm{m}$ 以下, 繰り返し周波数が $1 \mathrm{kHz}$ であることから, レーザーパルスが試料の同位置に複数回照射されること なく，常に新しい液体表面でX線発生が誘起されている と考えられる。偏光制御には い, 円/楕円偏光あるいは斜め直線偏光とした上で対物 レンズ $($ Mitutoyo/M Plan Apo × 10, NA=0.28)を用いて 蒸留水液膜表面に集光照射した。焦点でのレーザーパ ワーはレーザー光強度が $0.30 \mathrm{~mJ} / \mathrm{pulse}$ 以下のとき, $4.3 \times 10^{14} \mathrm{~W} / \mathrm{cm}^{2}$ 以下と見積もられる.X線検出には, 強 度測定用としてGM計数管 (Health Physics Instruments/ HPI5000 cypher) を, 発光スペクトル測定用としてCZT半 導体検出器(AMPTEK/XR-100T-CZT) をそれぞれ用い た。レーザー焦点から検出器までの距離は $5 \mathrm{~cm}$ とし, 検 出角度はレーザーの入射方向に対して90度とした。いず れの測定においても単一光子測定を実現するため, Poisson分布を考慮し100 counts/sec. 以下となるように検 出器の入力空の大きさを調整した上でX線を検出した. 実験は室温, 大気圧下で行った。

\section{3. 結 果}

Fig. 2に円/楕円偏光あるいは斜め直線偏光を励起光と した時のX線発光強度を示す。ここで蒸留水液膜の法線 に対する励起光の入射角度は60度とし, レーザー光強度 は0.30 mJ/pulseとした.ここでp偏光から, 楕円/円偏光 あるいは斜め直線偏光を経て $\mathrm{s}$ 偏光と変化させて行くに 従い, レーザー光強度は一定にも関わらずX線発光強度 が単調減少しているのが分かる。また $\mathrm{p} / \mathrm{s}$ 偏光比が同じ であるにもかかわらず，X線発光強度が斜め直線偏光よ り円偏光でより高い. さらに各波長板の後, 液膜試料の 直前に偏光ビームスプリッターを挿入することでs偏光 成分を除去し，楕円/円偏光あるいは斜め直線偏光のp 偏 光成分のみを励起光として照射した時のX線発光強度を Fig. 3 (a)に示す。これより明らかに, 楕円/円偏光ある いは斜め直線偏光励起において $\mathrm{s}$ 偏光成分がX線発光機 構に対して抑制的に作用していることが強く示唆され た. そこでp偏光成分のレーザー光強度を $0.15 \mathrm{~mJ} / \mathrm{pulse}$

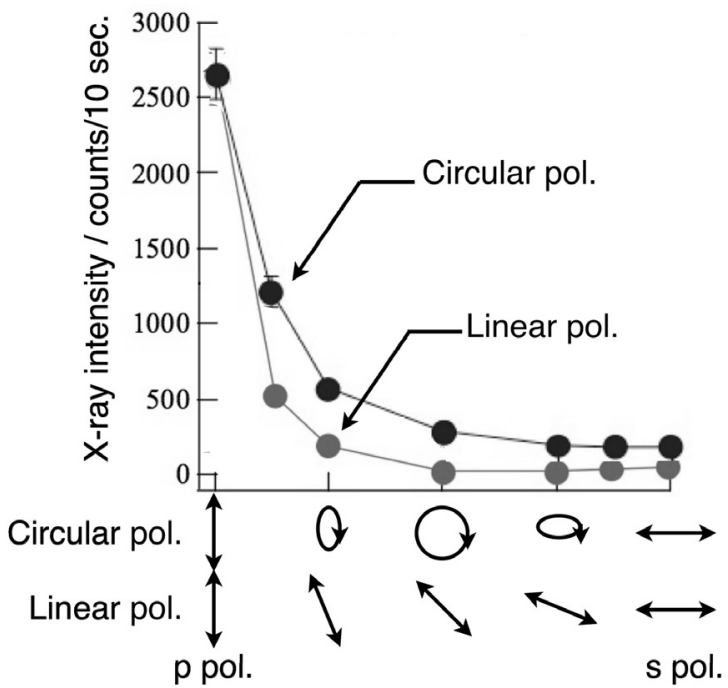

Laser intensity ratio of $p$ pol. component

Fig. $2 \mathrm{X}$-ray intensity as a function of laser polarization.

とした時の円偏光あるいは斜め直線偏光 ( $\mathrm{s}$ 偏光強 度 $=0.15 \mathrm{~mJ} / \mathrm{pulse}$ ）を励起光とするX線発光スペクトル測 定を行った (Fig. 3 (b))。ここでもp偏光成分のみを照射 した時が最もX線発光強度が高く,さらにBoltzmann分

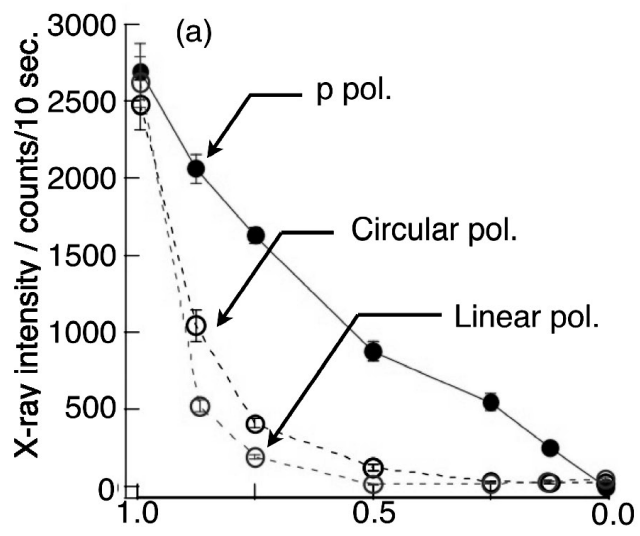

Laser intensity of $p$ pol. component ratio

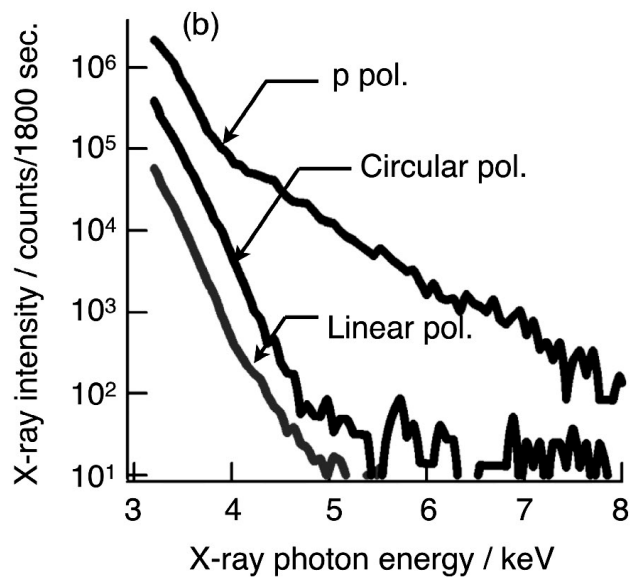

Fig. $3 \mathrm{X}$-ray intensity as a function of laser intensity depending on laser pol. (a) and X-ray emission spectra depending on laser pol. (b). 
布で近似し求められる電子温度も, $\mathrm{p}$ 偏光, 円偏光, 斜 め直線偏光の時, それぞれ $0.23 \mathrm{keV}$ (高エネルギー側で は0.51 keV)，0.21 keV，0.21 keVと得られた。ここでs偏 光成分の効果を更に明確にするために, p 偏光成分の レーザー強度を $0.1 \mathrm{~mJ} / \mathrm{pulse}$ と一定にした上で, s偏光強 度を変化させてX線発光強度を測定したところ (Fig. 4)， ここでもs偏光強度の増加に対して単調にX線強度は減 少した。より詳細に解析を行ったところ, 円偏光におけ る楕円率が 0.25 , 斜め直線偏光では偏光面の傾きがおよ そ14度という励起条件においても, X線発光強度はs偏 光成分が皆無の時と比べ半分あるいは $1 / 3$ となった。 こ れらの結果は，X線発光強度がレーザーの偏光面に対し て非常に敏感であることを示している.

これらの実験結果は, p偏光成分のレーザーパルスに よる共鳴吸収が優位であると予想される入射角度が 60 度 のときに得られた結果である。レーザー照射からパルス X線発生に至る過程は, 共鳴吸収以前に多光子イオン 化, 逆制動輻射, 2次電子放出など多様であり, それら 多くの過程を経た上でX線発光強度や電子温度は決定さ れる，そこで，液膜へのレーザー入射角度を0度として 同様の実験をつづいて行った。こうした条件では共鳴吸

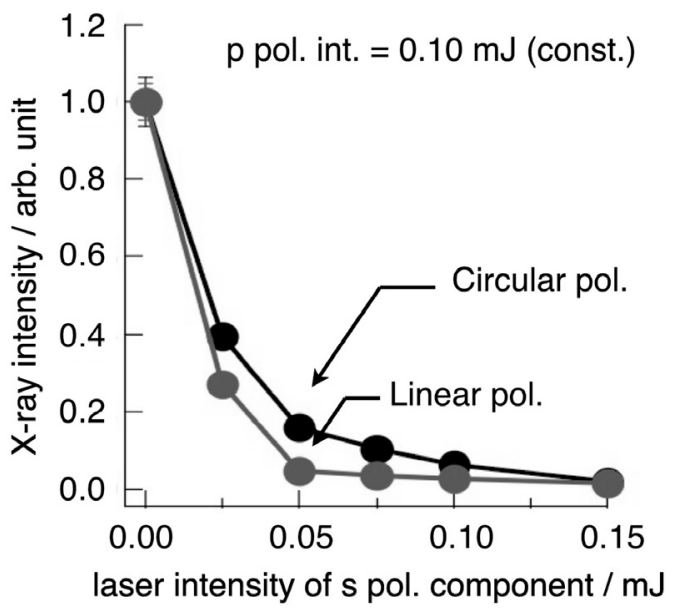

Fig. $4 \mathrm{X}$-ray intensity as a function of s pol. component laser intensity.

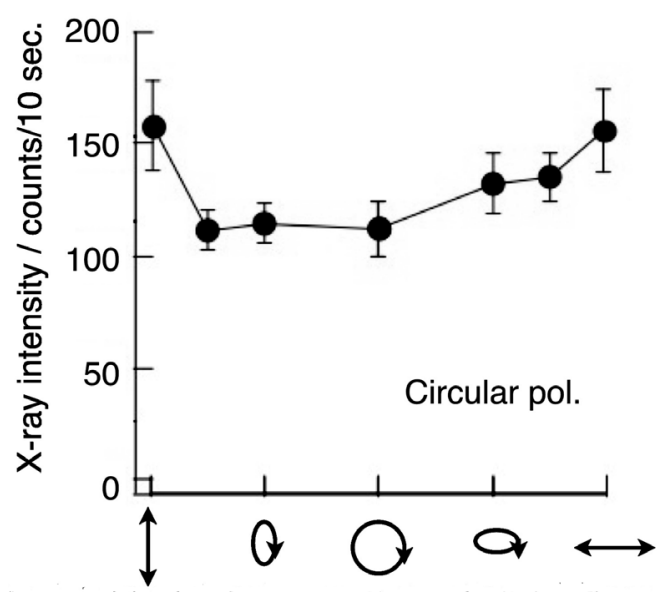

Fig 5 X-ray intensity as a function of laser polarization when the laser incident angle is 0 degree.
収の効果が比較的低いと考えられる。その結果Fig. 5に 示すように, 円偏光励起条件下では直線偏光 ( $\mathrm{p} / \mathrm{s}$ 偏光) 励起の場合と比べてX線発光強度が減少したことから, 上述の共鳴吸収以外の過程に対してもレーザーの偏光が 大きく影響していると考えられる.

\section{4. 考察}

X線発生の初期段階として高強度レーザー場によるイ オン化, すなわち多光子イオン化やトンネルイオン化が 考えられる。今回用いたレーザーの強度は最高で $0.30 \mathrm{~mJ} / \mathrm{pulse}$, パルス幅は390 fs(ネガティブチャープ),

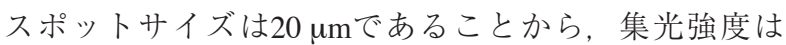
$4.3 \times 10^{14} \mathrm{~W} / \mathrm{cm}^{2}$ と見積もられるが，X線の発生過程にお けるイオン化は励起パルスの前半部で起こると考えられ るため, 初期イオン化が誘起される時点における集光強 度は数桁低下すると考えられ, 本実験では多光子イオン 化が支配的であると考えられる。続く二次電子放出など に伴い液膜表面において電子密度が上昇し生成したプラ ズマ中において，電子はレーザー光のエネルギーを逆制 動輻射過程によって吸収すると考えられる。これらの過 程を経て電子密度が上昇し，プラズマが臨界密度に達し レーザー光を反射するようになると, $\mathrm{p}$ 偏光のレーザー では共鳴吸収が効率よく誘起される。この共鳴吸収によ りさらに高いエネルギー電子が生じ，高エネルギー電子 の制動輻射あるいは内殼励起によりX線発生に至ると考 えられる。

これらのX線発生過程への偏光の影響について考察を 行う。まず，多光子イオン化について，固体や気体への レーザー照射時における偏光の影響は数多く研究されて おり, 円偏光に比べて直線偏光が有利であるという報告 がある ${ }^{25-29)}$. 一方で，電子の逆制動輻射過程において は, 円偏光の方が直線偏光に比べて効率的であるという 報告がなされている ${ }^{30)}$.このようなイオン化や電子の光 エネルギー吸収過程への偏光の影響が, X線の発生にも 影響していると考えられる。例えば，Fig. 5に示す垂直 入射における円偏光での発光強度の減少はイオン化によ る影響と考えることができる．またFig. 2の等しい偏光 比での発光強度の違いは, 多光子イオン化や逆制動輻射 過程への偏光の影響と考えられるが，これらを明確に区 別し解析することは現段階では難しい.

共鳴吸収への偏光の影響についてはFig. 4に示すよう に，たとえp偏光成分の一定值であっても，わずかに偏 光が楕円あるいは斜めになるだけでX線発光強度は大き く減少する。これはプラズマによるレーザーの共鳴吸収 は, p偏光とs偏光と成分に分離して考えるのではなく, 電場の回転や傾きに影響を受けるのではないかと考えら れる。こうした結果を説明するために「プラズマ中の電 子は，プラズマを誘起したレーザーの電場方向にのみ振 動する」という仮定を立てて考察を行う。共鳴吸収は臨 界点において，プラズマ中の電子の振動とレーザーのプ ラズマ密度方向への電場が共鳴して電子の疎密波が生 じ，電子がエネルギーを得る過程である。上記仮定か 
ら, 多光子イオン化や二次電子放出によって生成し, 逆 制動輻射によってエネルギーを吸収した電子はレーザー の電場, つまり偏光方向にのみ振動する. 偏光がp偏光 の場合, 生成した電子はp偏光の向きに振動し, レー ザー光の反射点における電場もプラズマ密度勾配の向き に振動するため電子と電場は共鳴し共鳴吸収が誘起され る. 一方でレーザーの偏光が p 偏光から傾いている場合, 生成した電子はプラズマの密度方向から傾いた方向に振 動するようになるが，レーザーの偏光が傾いていても入 射角は変化しないため, レーザーの電場成分はプラズマ 密度勾配方向へ伝播する，従ってレーザーの偏光が傾い ていると，伝播するレーザー電場とプラズマ中の電子の 振動方向がずれて共鳴が誘起される確率が相対的に減少 し，共鳴吸収が阻害されると考えられる。その結果X線 強度が減少したと考えられる。

\section{5. まとめ}

本稿では, 円偏光ならびに斜め直線偏光と従来のp偏 光励起に伴う蒸留水からのフェムト秒レーザーパルス誘 起パルスX線発生について比較検討を行った。レーザー の偏光がp偏光からわずかに変化するだけでX線の発光 強度が減少するという結果を得た。レーザーを垂直入射 させた実験から，共鳴吸収を除いた条件におけるX線発 光強度の変化を観測し， 円偏光や斜め直線偏光では共鳴 吸収の阻害が生じていると考えた。 円偏光励起は, 多光 子イオン化や逆制動輻射過程へ影響を及ぼすと考えられ る。また共鳴吸収への偏光の影響は，プラズマ中におけ る電子の振動がレーザーの偏光方向に依存し, その振動 方向と $\mathrm{p}$ 偏光の電場方向が異なることによると結論し た。

\section{参考文献}

1) M. M. Murnane, H. C. Kapteyn, M. D. Rosen, and R. W. Falcone: Science 251 (1991) 531.

2) Y. Oishi, T. Nayuki, K. Nemoto, Y. Okano, Y. Hironaka, K. Kondo, and K. G. Nakamura: Appl. Phys. Lett. 79 (2001) 1234.

3) T. Ditmire, J. Zweiback, V. P Yanovsky, T. E. Cowan, G. Hays, and K. B. Wharton: Nature 398 (1999) 489.

4) A. Hishikawa, A. Iwamae, and K. Yamanouchi: Phys. Rev. Lett. 83 (1999) 1127.

5) J. Kou, V. Zhakhovskii, S. Sakabe, K. Nishihara, S. Shimizu, S. Kawato, M. Hashida, K. Shimizu, S. Bulanov, Y. Izawa, Y. Kato, and N. Nakashima: J. Chem. Phys. 112 (2000) 5012.

6) H. Kono, S. Koseki, M. Shiota, and Y. Fujimura: J. Phys. Chem. A. 105 (2001) 5627.

7) D. Umstadter: Phys. Plasmas 8 (2001) 1774.

8) A. Maltuska, Th. Udem, M. Uiberacker, M. Hentschel, E. Goulielmakis, C. Gohle, R. Holzwarth, V. S. Yakovlev, A. Scrinzi, T. W. Haensch, and F. Krausz: Nature 421 (2003) 611.

9) S. Martellucci, C. Bellecci, M. Francucci, P. Gaudio, M. Richetta D. Toscano, A. Rydzy, M. Gelfusa, and P. Ciuffa: J. Phys. Condens. Mat. 18 (2006) S2039.

10) Majed Chergui and Ahmed, and H. Zewail: ChemPhysChem 10 (2009) 28.

11) E. G. Villora, K. Hatanaka, H. Odaka, T. Sugawara, T. Miura, H. Fukumura, and T. Fukuda: Solid State Commun. 127 (2003) 385.

12) L. Zhao. H. Odaka, H. Ono, S. Kajimoto, K. Hatanaka, J. Hobley, and H. Fukumura: Photochem. Photobio. Sci. 4 (2005) 113.

13) D. Ehrentraut, Kagamitani, A. Yoshikawa, T. Fukuda, H. Sato, J. Pechjal, M. Nikl, H. Odaka, K. Hatanaka, and H. Fukumura: Journal of Materials Chemistry 16 (2006) 3369.

14) J. Pejchal, Y. Kagamitani, D. Ehrentraut, H. Sato, H. Odaka, K. Hatanaka, M. Nikl, A. Yoshikawa, H. Fukumura, and T. Fukuda: Phys. Stat. Sol. (c) 4 (2007) 942.

15) H. Odaka, T. Miura, K. Hatanaka, S. Wiebel, and H. Fukumura: J. Phys. Chem. C 113 (2009) 11969.

16) H. Witte, M. Silies, T. Haarlammert, J. Hüve, J. Kutzner, and H. Zacharia: Appl. Phys. B 90 (2008) 11.

17) B. Kim, B. Ahn, D. Lee, J. Kim, and D. Kim: Appl. Phys. Lett. 88 (2006) 141501.

18) R. J. Tompkins, I. P. Mercer, M. Fettweis, C. J. Barnett, D. R. Klug, L. G.Porter, I. Clark, S. Jackson, P. Matousek, A. W. Parker, and M. Towrie: Rev. Sci. Instrum. 69 (1998) 3113.

19) W. Fullagar, M. Harbst, S. Canton, J. Uhlig, M. Walczak, C. G. Wahlström, and V. Sundström: Rev. Sci. Instrum. 78 (2007) 115105

20) K. Hatanaka, T. Miura, and H. Fukumura: Appl. Phys. Lett. 80 (2002) 3925

21) K. Hatanaka, T. Miura, and H. Fukumura: Chem. Phys. 299 (2004) 265.

22) K. Hatanaka, H. Ono, and H. Fukumura: App. Phys. Lett. 93 (2008) 064103.

23) K. Hatanaka, T. Ida, H. Ono, H. Fukumura, S. Juodkazis, and H. Misawa: Opt. Express 16 (2008) 12650.

24) K. Hatanaka and H. Fukumura: Chapter 9 in "Three-Dimensional Laser Microfabrication: Principles and Applications", H. Misawa and S. Juodkazis, Eds. Wiley (2006) ISBN 352731055X.

25) A. K. Dharmadhikari, A. S. Sandhu, J. A. Dharmadhikari, A. Mishra, and G. R. Kumar: Appl. Phys. B. 79 (2004) 235.

26) G. D. Gillen, M. A. Walker, and L. D. Van Woerkom: Phys. Rev. A 64 (2001) 043413

27) J. McKenna, M. Suresh, B. Srigengan, I. D. Williams, and W. A. Bryan, E. M. L. English, S. L. Stebbings, W. R. Newell, ICE Turcu, J. M. Smith, E. J. Divall, C. J. Hooker, A. J. Langley, and J. L. Collier: Phys. Rev. A 73 (2006) 043401.

28) V. V. Temnov, K. Sokolowski-Tinten, P. Zhou, A. El-khamhawy, and D. von der Linde: Phys. Rev. Lett. 97 (2006) 237403.

29) D. Mathur, M. Krishnamurthy, and F. A. Ra Jgara: Phys. Rev. A. 68 (2003) 023407.

30) S. M. Hooker and N. David: Phys. Rev. E. 72 (2005) 036402. 